Article

\title{
Location of Cows and Pigs in Suburban Areas of Polish Metropolitan Centers
}

\author{
Benedykt Pepliński $($ )
}

Faculty of Economics and Social Sciences, Department of Law and Enterprise Management in Agribusiness, Poznan University of Life Sciences, 60-637 Poznan, Poland; peplinski@up.poznan.pl

Received: 30 January 2020; Accepted: 24 March 2020; Published: 26 March 2020

\begin{abstract}
The main aim of this paper was to assess the impact of socioeconomic and agricultural factors on cow and pig density in suburban areas located up to $50 \mathrm{~km}$ from the 11 biggest cities in Poland. This study relied on data retrieved from all municipalities located within $50 \mathrm{~km}$ from central cities. The impact of the previously mentioned socioeconomic and agricultural factors was assessed using the Pearson correlation coefficient, analysis of variance (ANOVA), and regression analysis. This study shows that the lowest cow and pig density was recorded in the two inner rings. From 1996 to 2010, the gap between them and the levels recorded in other rings became much more pronounced. The analysis only corroborated the high correlation between livestock (cow and pig) density and the share of corresponding livestock farms in the total number of farms as well as the average herd size. Regarding other agricultural and socioeconomic factors, the correlation was weak or low except for a moderate correlation between the entrepreneurship indicator and pig density. The regression analysis demonstrated that the share of cow and pig farms in the total number of farms, average herd size, residential housing density, and unemployment rate had a significant impact on the density of animal groups considered.
\end{abstract}

Keywords: Sinclair's theory; cow density; pig density; metropolitan city; suburbia

\section{Introduction}

In the era of centrally planned economies, mismanagement, and poor efficiency resulted in a general deficiency of both industrial goods and food. This resulted in the rationing of key food products (based on ration coupons) such as meat, butter, sugar, chocolate, etc. The permanent deficiency of food, and the related policy for minimizing the reallocation of agricultural land to non-agricultural uses, also restricted the development of suburban housing. The state-controlled residential construction sector played a dominant role and was primarily focused on multi-story buildings, which also minimized the demand for agricultural land. After 1990, the introduction of the free market economy and the liberalization of the construction law in Poland brought considerable acceleration of the urban development process, mostly in suburban zones. Growth was experienced in the sector of suburban single-family homes and small buildings with several flats. The development of residential housing, roads, and industrial zones as well as the discontinuation of agricultural use of the less fertile soils in 1990-2010 contributed to a decline in the area of agricultural land in Poland by as much as $17.2 \%$.

In the case of suburban areas of large metropolises, settlement expansion also results in major functional changes in settlement systems and in their social and economic conditions [1,2]. This is connected with a gradual process of pushing agriculture out of suburban areas through the marginalization of its production, social, and environmental functions [3-5]. In the mid-1900s, Sinclair noted that urban expansion and the anticipation of urban uses of agricultural land located near big cities leads to the 
extensification of agricultural production, and that production becomes more intense as the distance from central cities grows (reversed von Thünen's rings) [6-8].

Research shows that the gradual construction of residential buildings results in the growth of irresolvable complaints on agricultural nuisances related to animal and plant production (e.g., odors, noise, and dustiness). Consequently, animal depopulation accelerates while farmers are less willing to develop animal production [9-13]. The development of the largest cities and their outskirts [metropolitanization] results from the increasingly popular settlement of residents in suburban areas present in Poland [1].

The international literature includes many papers addressing the location of agricultural production in urban areas or around metropolitan areas [11,14-16]. In turn, Polish researchers focused mainly on land uses in Polish cities and metropolises [1,17-21]. They show a large decline in agricultural land, which indirectly reduces feed production and animal numbers. Furthermore, research showed that migrations, the increase in population density, and the increase in the number of enterprises (reduction of unemployment rate) all contribute to a growth in demand for land for non-agricultural uses. As a consequence, agricultural land is reallocated for other purposes [1,22-25].

In view of the above, the main aim of this paper was to assess the impact of socioeconomic and agricultural factors on cow and pig density in suburban areas located within up to $50 \mathrm{~km}$ from Poland's 11 biggest cities in 2010. Animal density figures as recorded in the areas covered by this analysis in 1996 will also be presented in order to trace the relevant trends. This study is an extension of the research undertaken by Pepliński [5], who, in chapter 7, described changes in the pig and sow population for Poland's 11 largest cities using rings with a radius of $25 \mathrm{~km}$.

Two research hypotheses were also formulated.

- As the distance from the central city reduces, so does cow and pig density;

- Agricultural and socioeconomic factors have an impact on cow and pig density.

\section{Theoretical Background}

The theory of agricultural location, with von Thünen as the main contributor, is likely the geographic concept most widely used around the globe. In the von Thünen's rings (a timeless model for agricultural land use and lease), the location of production of specific agricultural raw materials relative to a city is dependent upon their capacity to generate income [26]. It was used in agricultural systems underpinned by any possible technologies across all five continents. However, research was mostly carried out in developing countries or, sometimes, in regions living mainly from farming because of the limited number of factors affecting incomes derived from the use of rural land [27]. The versatility of the von Thünen's location theory is reflected not only by the fact that it was adapted to explain industrial processes, likely independently by Launhardt (1882) and Weber (1909) [28,29], but also by recent research on agriculture and beyond. The above is evidenced, for instance, by research on the impact of beef and milk production profitability on Amazonian deforestation [30], the structure of land use depending on its distance from tourist cities [31], the scale of raw material extraction operations [32], and the ability to use urban waste compost in areas surrounding large urban centers [33].

Agricultural industrialization and the related increase in yields, improvements in production efficiency, work organization, and the development of transport, cooling technology, and of the processing industry, etc. reduced the importance of transport costs, which is the basic factor for agricultural production location according to von Thünen. Nevertheless, the basic concept that the location of speculative activities depends on the economic rent they generate continues to be valid, and can be used in explaining the way agricultural land is used [20]. For instance, that concept can be relied upon to model the use of land [34-36], to explain the agricultural evolution and the deforestation process $[30,37,38]$, and to develop the theory of urban land lease $[39,40]$ and the theories on the role of regulatory bodies [41].

A direct reference to von Thünen's rings was also made by Reference [6]. In addition to transport costs and lease rates, his analysis took into consideration three other factors, which he believed had 
an impact on land uses in modern industrial zones, i.e., a modern production organization that gives preference to large-scale production operations and mass transport of agricultural produce, the domestic or worldwide market, and the competition between different agricultural uses of land by taking into account the growing competitiveness of non-agricultural uses [7]. He also advanced a thesis on the reversed von Thünen's rings, following from the fact that agricultural production intensity (output, performance) increases together with the distance from the urban center $[1,10,27,42,43]$. According to Sinclair, the decreasing intensity of agriculture in peripheral zones of urban centers was caused by the anticipation of urban uses of agricultural land. This, in turn, resulted from urban development (especially including suburban settlement), increasing prices of land and other goods, increasing wages, and the emergence of non-agricultural employment opportunities $[5,7,44]$. The increase in land lease rates, land prices, and wages in areas with a high concentration of industrial activities was already noted by von Thünen [26]. Low productivity of agricultural labor, and poorly profitable, capital-intensive, small-scale production activities are the reason why, as agricultural land becomes more likely to be converted to non-agricultural uses, it is less likely to maintain agricultural production or increase its scale and intensity [6]. This is especially difficult in the long run because the farmers are unable to increase their farms' area (versus leasing land from speculators investing in land), and because capital-intensive investments have long payback periods and, therefore, carry an additional risk in suburban areas [45]. Suburban land is seen as a safe long-term investment, and, therefore, is not considered as a productive input but rather as an investment that will provide capital gains in the future [46,47]. As long as there is potential for future conversion into non-agricultural uses, and as long as the city (together with its services and residents) keeps "moving closer," land will increase its value $[10,46,48-51]$. The speculative purchase volume is greater than the amount of land to be developed in the foreseeable future [48]. Therefore, investors not interested in agricultural production often lend their land to farmers in return for a fee below the fair market value $[6,10,47,48,52,53]$. At higher levels of non-agricultural land taxation, this is beneficial for both sides. However, as the city grows, the supply of leased land decreases. Furthermore, the land conversion schedule is beyond the control of the farmer, which also does not encourage long-term investments [10].

The fast, uncontrolled decline in agricultural land area, as witnessed after 1990 in many countries undergoing economic transformation, gave rise to concerns about the capacity to feed these nations and the global population $[43,47,54-57]$. These concerns seem reasonable in view of the expected $70 \%-110 \%$ increase in demand for food by 2050 (with 2005-2010 as the base period), resulting from rapid population growth, enhancement in welfare levels, and changes in diet [58-61]. Therefore, there is need for implementing a land protection policy at a global level. As noted by Furuseth and Pierce, agricultural land protection schemes, such as those put in place in Oregon and British Columbia, enjoyed public support and were a great success as they slowed down the conversion of land into non-agricultural uses [62]. Moran [63] used the example of Auckland suburbs in demonstrating the effectiveness of institutional schemes for land protection [43,63]. However, these discoveries are denied by Bounce who assessed the outcomes of agricultural land protection schemes in North America (starting from the 1970s) and found that the public policy for land protection is a distorting factor and seems to have temporary and limited success [64].

\section{Characteristics of the Research Area}

\subsection{Central Cities}

In Poland, industrialization and urbanization processes started relatively late (ca. two centuries later than in most Western European countries), which makes it a country with a relatively low level of urbanization [65]. With a population of 38.4 million, Poland has only four cities in the EU's top 50, including Warsaw ranked 9th, and Krakow, Łódź, and Wrocław ranked 26th, 29th, and 34th, respectively. In $2018,60 \%$ of the population lived in rural areas. In recent years, as a result of a negative net migration rate and a negative population growth rate, the urban population has started decrease 
while the rural population has been growing due to a positive net migration rate and a slightly positive population growth rate [66]. However, the urbanization process actually keeps progressing because the greatest population growth is experienced in suburban areas in Poland's biggest cities. They also include rural municipalities with localities of several thousand people.

Together, the 11 central cities covered by this analysis had more than 6.5 million residents, i.e., $17 \%$ of the Polish population. The total area covered by the study accounted for $17.3 \%$ of the national territory and was home to nearly $40 \%$ of the national population, i.e., 15.3 million people (Table 1 ). Furthermore, this area was home to $30.4 \%$ of residential buildings and to nearly half of economic operators active in Poland. The most populated area covered by this study were the cities and areas surrounding Warsaw and Katowice (ca. three million people). Areas located around Białystok, Lublin, and Szczecin had a population below one million. The corresponding figures for other cities varied from 1.1 to 1.5 million people.

Table 1. General characteristics of central areas covered by the analysis (in 2010).

\begin{tabular}{cccccc}
\hline Central City & $\begin{array}{c}\text { Number of } \\
\text { Municipalities } \\
\text { Covered }\end{array}$ & $\begin{array}{c}\text { Population of } \\
\text { Central Cities } \\
\text { (Thousand) }\end{array}$ & $\begin{array}{c}\text { Population } \\
\text { (Thousand) }\end{array}$ & $\begin{array}{c}\text { Number of } \\
\text { Residential Buildings } \\
\text { (Thousand) }\end{array}$ & $\begin{array}{c}\text { Number of } \\
\text { Economic Operators } \\
\text { (Thousand) }\end{array}$ \\
\hline Białystok & 32 & 294.2 & 559.8 & 90.0 & 49.0 \\
Bydgoszcz & 42 & 364.4 & 1110.2 & 111.8 & 111.1 \\
Gdańsk & 30 & 460.5 & 1171.3 & 309.4 & 151.2 \\
Katowice & 69 & 311.4 & 3057.7 & 225.5 & 304.8 \\
Kraków & 55 & 757.7 & 1511.5 & 131.3 & 163.6 \\
Lublin & 52 & 349.5 & 796.2 & 143.1 & 69.7 \\
Łódź & 53 & 730.6 & 1296.4 & 53.4 & 136.9 \\
Poznań & 41 & 555.6 & 1161.1 & 326.1 & 171.9 \\
Szczecin & 16 & 410.2 & 680.0 & 124.7 & 97.2 \\
Warszawa & 62 & 1700.1 & 2832.5 & 1182.6 & 493.6 \\
Wrocław & 41 & 630.7 & 15359.3 & 1781.6 & 155.9 \\
\hline Total & 493 & 6565.0 & 39.9 & 30.4 & 49.3 \\
\hline Poland $100 \%$ & 19.9 & Source: Own elaboration based on the data [67]. &
\end{tabular}

\subsection{Characteristics of Agriculture}

In Poland, during the era of centrally planned economies (before 1990), despite the agrarian reforms, the average farm size did not change and was ca. 7.0 ha [68]. This was the key factor behind the fragmentation of animal production as well. The domination of small individual farms made Poland stand apart from other socialist countries. Today, it is the reason why agriculture fails to adapt to the situation in world agricultural markets. Although production concentration and industrialization accelerated sharply after 1990, they are still not fast enough compared to other EU countries. This is true both for the average farm size and for the average herd size of key animal species. In terms of each of these criteria, Poland (together with Romania) is among the EU countries with the less advanced agricultural concentration processes [69-73]. This is especially detrimental in the context of the rapidly growing minimum scale of farming operations, which, in most European countries with an agricultural structure similar to that found in Poland, is more than 100 cows and several thousand pigs (vs. 20-29 cows and 400-999 pigs in Poland) [69]. Unfortunately, only around half of the Polish cow and pig population is kept in herds that have a development potential. Especially in the case of pigs, this presents the risk of deepening the crisis affecting that market. Another unfavorable aspect is the fact that many of the largest farms (most of them established as a continuation of state-owned agricultural holdings) abandon animal production, especially in the context of the Nitrates Directive, which allows only $30 \%$ of organic fertilizers to be used outside livestock farms [74].

After 1990, the territorial concentration of basic animal species started to accelerate as well. This is because, after 1990, most state-owned and cooperative processing facilities were liquidated. They 
were located in each district and had milk and livestock collection points in each municipality. In the newly established private companies and in dairy cooperatives under restructuring, agricultural raw materials were collected directly from farms. Furthermore, higher prices were offered as a premium to suppliers of larger batches of agricultural produce. In 1990, the production of basic vegetable and animal raw materials was distributed evenly across the national territory. However, due to progressing concentration, already in 2010, half of the pig and cow population was located in three out of the sixteen voivodeships [5,75-77].

Concentration processes also slowed down by the large share of farms whose owners see their farming income as a supplement to what they earn in non-agricultural sectors. The slowdown is also driven by direct payments and other Union programs of agricultural support [78]. The areas covered by this study are also clearly affected by structural problems. There were 330,000 farms (which is more than the total number of farms in Germany) using 2.3 million hectares of agricultural land, i.e., 6.8 ha on average (Table 2). Nearly 62,000 farms kept 5.3 cows on average. A total of 65,000 farms kept 37.0 pigs on average. These figures are several percent lower than the average levels for Poland. The largest farms, both in terms of area and average animal numbers, were located in the region of Bydgoszcz and Poznan. The smallest, in turn, was found near Kraków, Katowice, Lublin, and Warsaw.

Table 2. General characteristics of agriculture in central areas covered by the analysis (in 2010).

\begin{tabular}{|c|c|c|c|c|c|c|}
\hline Central City & $\begin{array}{l}\text { Agricultural } \\
\text { Land } \\
\text { (Thousand ha) }\end{array}$ & $\begin{array}{c}\text { Cow } \\
\text { Numbers } \\
\text { (Thousand) }\end{array}$ & $\begin{array}{c}\text { Pig } \\
\text { Numbers } \\
\text { (Thousand) }\end{array}$ & $\begin{array}{c}\text { Total Number } \\
\text { of Farms } \\
\text { (Thousand) }\end{array}$ & $\begin{array}{l}\text { Number of } \\
\text { Cow Farms } \\
\text { (Thousand) }\end{array}$ & $\begin{array}{l}\text { Number of } \\
\text { Pig Farms } \\
\text { (Thousand) }\end{array}$ \\
\hline Białystok & 276.0 & 92.0 & 132.9 & 28.51 & 9.25 & 6.21 \\
\hline Bydgoszcz & 295.5 & 39.9 & 497.6 & 20.86 & 4.81 & 7.15 \\
\hline Gdańsk & 139.4 & 15.5 & 126.4 & 12.42 & 3.39 & 3.34 \\
\hline Katowice & 112.4 & 10.3 & 106.1 & 27.18 & 2.17 & 3.04 \\
\hline Kraków & 194.1 & 19.0 & 157.0 & 72.91 & 10.06 & 11.15 \\
\hline Lublin & 313.4 & 41.0 & 246.4 & 64.47 & 12.66 & 13.98 \\
\hline Łódź & 272.2 & 66.4 & 507.0 & 36.77 & 10.90 & 8.56 \\
\hline Poznań & 239.5 & 21.7 & 531.4 & 15.45 & 2.69 & 6.35 \\
\hline Szczecin & 83.4 & 3.6 & 19.6 & 6.15 & 0.46 & 0.67 \\
\hline Warszawa & 159.4 & 13.7 & 29.6 & 30.86 & 3.81 & 1.83 \\
\hline Wrocław & 248.3 & 6.6 & 51.1 & 26.50 & 1.50 & 2.80 \\
\hline Total & 2333.7 & 329.7 & 2405.4 & 342.09 & 61.69 & 65.05 \\
\hline Poland $=100 \%$ & 17.9 & 13.1 & 18.3 & 18.4 & 13.6 & 16.4 \\
\hline
\end{tabular}

\section{Methodology}

The main sources of data were information available in the Local Data Bank of the Central Statistical Office of the Republic of Poland as well as literature that was found using keywords such as Thünen theory, Thünen circles, Sinclair theory, suburban areas, etc. The databases Scopus, JSTOR, Wiley Online Library and others were used for this purpose. In the period 2018-2020, about 450 publications were searched through, which included about 100 used to describe current problems occurring in suburban areas described in chapters 1 and 6, methodological issues in chapter 4, and theoretical aspects in chapter 2.

Most data available at the municipality level is from 2010. The analysis intentionally excludes land, animals, and other parameters of organizations other than individual farms because data collection methods used by the Central Statistical Office does not allow us to specify the actual location of agricultural production. This follows from the fact that, in some cases, the farm (agricultural enterprise) is based in a metropolitan area while most (if not all) of its agricultural production facilities are located elsewhere [1]. As shown in a publication by the Central Statistical Office [79], individual farms are virtually not affected by that problem. Central cities were defined as the top 10 largest cities in Poland. This study also included Białystok, which is Poland's 11th largest city and the largest one in the 
northeast part of the country. The selection of cities was based on their dominant role in the local market. The anticipation of urban uses of agricultural land is mostly manifested in the biggest cities.

This study relied on data retrieved from all municipalities located within $50 \mathrm{~km}$ from central cities. The municipalities, except for central cities, had a similar area, population close to normal, and none of them had outliers. The study was carried out at a municipality level based. Due to the lack of more exact data, this study assumes that parameter values (e.g., area, animal numbers) for the entire municipality are located at a distance equal to the shortest route between the seat of municipal authorities and the center of the central city, as proposed by Google Maps.

The impact of central cities declines as the distance increases, and, therefore, five 10-km rings were identified around each of the 11 selected central cities. As a consequence, subsequent rings had an increasingly large study area. In the case of cities located close to the national border (Gdańsk, Szczecin), the remote rings were incomplete. Hence, it was necessary to carry out comparative analyses based on relative values.

Animal density per 100 ha of general land and per 100 ha of agricultural land can be used as the explained variable. The first one shows the absolute animal density, without taking account of environmental, production, and agricultural conditions affecting vegetable and animal production volumes (including the amount of agricultural land). If agricultural production is fragmented, as is the case in Poland, the area of agricultural land has a strong impact on the quantity of feed produced and, thus, on the pig production potential. In the case of cattle, these factors are nearly fully correlated. When it comes to pigs, the average purchased feeds account for about $50 \%$ of the feed used but can be nearly $100 \%$ for smaller producers [58]. However, the advantage of that variable is that it shows the actual animal density, which can also result from the limited amount of agricultural land. The second indicator takes account of agricultural land resources whose share decreases as urbanization progresses. However, simulations performed by the author in a broader context show the impact of other (mainly socioeconomic) factors on animal numbers. In view of the above, cow and pig density calculated as the number of animals per 100 ha of agricultural land was used as the explained variable in this study.

The explanatory variables selected to be used in this study (based on the availability of 2010 data at a municipal level) are as follows [1,5,22-25,45]:

1. Agricultural factors:

- $\quad$ share of agricultural land (AL) in total land area (\%),

- $\quad$ share of wasteland in total farm area (\%),

- $\quad$ share of cow and pig farms in the total number of farms (\%),

- $\quad$ average animal numbers (animals per farm keeping the animal species concerned),

2. Socioeconomic factors:

- $\quad$ population density (per $\left.\mathrm{km}^{2}\right)$,

- $\quad$ net migration rate (per 1000 population),

- $\quad$ residential housing density (number of residential buildings per $\mathrm{km}^{2}$ ),

- $\quad$ unemployment rate in the working-age population in $2011(\%)$,

- $\quad$ entrepreneurship level (economic operators per 10,000 working-age population),

- own income of municipalities includes: agricultural tax, property tax, vehicle tax, duty on actions under the civil law, shares in personal and corporate income taxes, stamp duties, income derived from the unit's own property, local fees, and other fees provided for by the law (PLN thousand per capita).

The Pearson correlation analysis was used to determine the impact of specific factors on the density of animals covered by this study. The calculations were based on a comparison of indicators from all central cities covered, separately for rings 1 to 5 and for all rings combined together. The study relied on indicator values for the municipalities covered. 
Regression analysis was implemented to examine the factors influencing stocking density. In this case, regression analysis allows us to determine the relevance and the direction of impact of selected variables (independent variables are listed above) on the stocking density of pigs and cattle (per 100 ha of UR) as a dependent variable.

The analysis of variance (ANOVA) was used to identify statistically significant relationships between the data analyzed [80]. In this test, the null hypothesis is that all group means $\mu(1,2, \ldots$, i) are equal ( $\mathrm{H} 0: \mu 1=\mu 2=\mu 3=\ldots=\mu \mathrm{i})$, whereas the alternative hypothesis is H1: a difference exists between two or more group means. Therefore, the alternative hypothesis is that at least two populations exist, which differ in the mean level. The decision to accept or reject the null hypothesis is based on the F-statistic calculated as: F = intra-group variance / inter-group variance. Inter-group variance is an indicator of the dispersion of means in each group covered by the comparison in relation to the general mean. Intra-group variance is an indicator of dispersion of results within the group where the result considered belongs. The analysis of variance was performed to check for the existence of statistically significant differences within the farm population covered by the study at $\alpha=0.05$. The results were interpreted using the arithmetic mean and the coefficient of skewness, which shows how asymmetric the distribution is around its mean as per the formula below [81].

\section{Results}

As expected, the share of agricultural land in total land area increased together with the distance from the center of the central city. Within $10 \mathrm{~km}$ from the center of the eight biggest cities in 2010, the share of agricultural land varied from $17.3 \%$ to $31.3 \%$ (Figure 1). It was lower (6.9\%) only in the case of Katowice, which is the largest of the 14 cities comprising the Silesian agglomeration. Conversely, the highest share of agricultural land was recorded in two cities in Eastern Poland. In Białystok, the share of agricultural land in the third and fourth ring was slightly higher than in the first ring due to large forested areas being located north and east from the city. In most other cities, the share of agricultural land increased together with the distance from city centers. The location of agricultural land was also important for its use. As the distance from the center increases, so does the average share of agricultural land under crops (from $53.2 \%$ in the first ring to more than $70 \%$ in rings 3 to 5 ) while the share of agricultural wasteland declines (from $5.6 \%$ in the center to $1.9 \%$ in the outer ring), and so does the share of wasteland owned by farms ( $8.3 \%$ and $2.1 \%$, respectively). An above-average share of wasteland owned by farms, especially in the central ring, was recorded in the three Polish metropolitan areas, i.e., Warsaw (19.8\%), Katowice (12.3\%), and Krakow (11.9\%). Conversely, the lowest levels were found both in the smallest central cities and in those located in the most agriculturally developed regions with a deficiency of agricultural land, i.e., Poznań, Łódź, and Bydgoszcz ( $2.9 \%-4.1 \%)$.

In most cities, cow density in the first ring was at a minimum level of up to five animals per 100 ha of agricultural land in 1996 (Figure 2). It reached the highest levels in Białystok (13.9), which is a region specializing in dairy production.

Pig density in the first ring in 1996 was high (with 32.3 animals/100 ha of agricultural land, on average). In the case of Krakow and Poznań, it was above 50 animals/100 ha of agricultural land (Figure 3). Such high-density levels were the consequence of many residents keeping a few pigs in buildings not suitable for animal rearing, such as workshops and garages. In that period, such activities were highly accepted by neighbors.

In most cities, cow density in the first ring in 2010 was at a minimum level of up to two animals per 100 ha of agricultural land (Figure 4). It reached the highest levels in Białystok (9.4), which is a region specializing in dairy production, and in Łódź (6.9). With regard to cities with a population of up to 0.5 million, a cow density close to the voivodeship-level average figure was usually found in the third or fourth ring. In the case of cities with a population of 0.5 to 1.0 million, it was in the fourth or fifth ring. When it comes to Warsaw, in none of the rings covered did the animal density exceed half of the average level for the Mazowieckie voivodeship. This was due to the cows being mostly concentrated in the northern and eastern part of the voivodeship. 
In the first ring of five cities, pig density did not exceed 10 animals per 100 ha of agricultural land (Figure 5). The highest levels were recorded in Poznań (46) and Łódź (94). This can be due to pigs being located in voivodeships with the highest concentration of pig stocks across Poland (over one-third of total pig stocks are kept there). Just like in the case of cows, pig density was at a level similar to the voivodeship average figure in rings two to four for smaller cities and in rings four to five for larger ones. However, the relationship is weaker than it was for cows. With regard to Warsaw, the pig density did not exceed half of the average level for the Mazowieckie voivodeship in any of the rings.
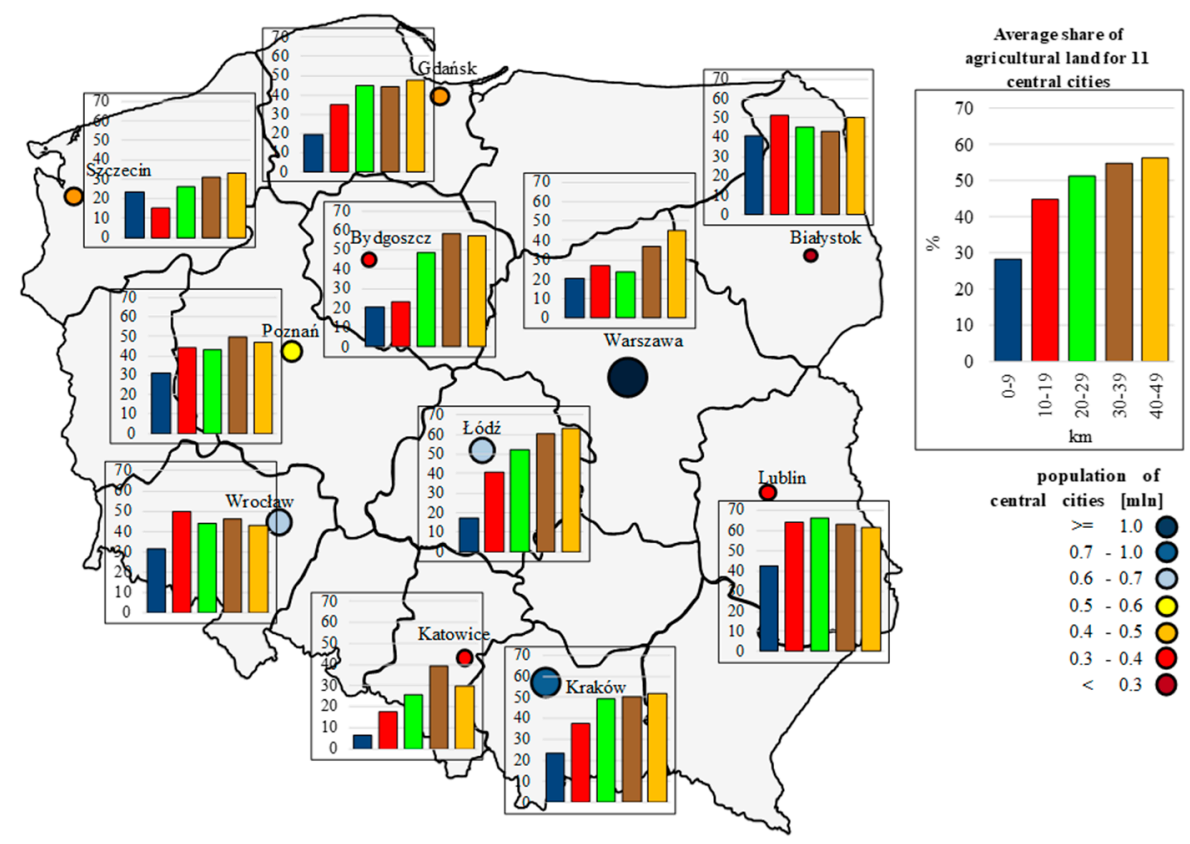

Figure 1. Share of agricultural land in total land area in Poland in 2010 with around 11 of the biggest cities in Poland (the unit and sequence of rings in voivodeships are as shown in the graph for the Polish territory). Source: own elaboration based on data [67].
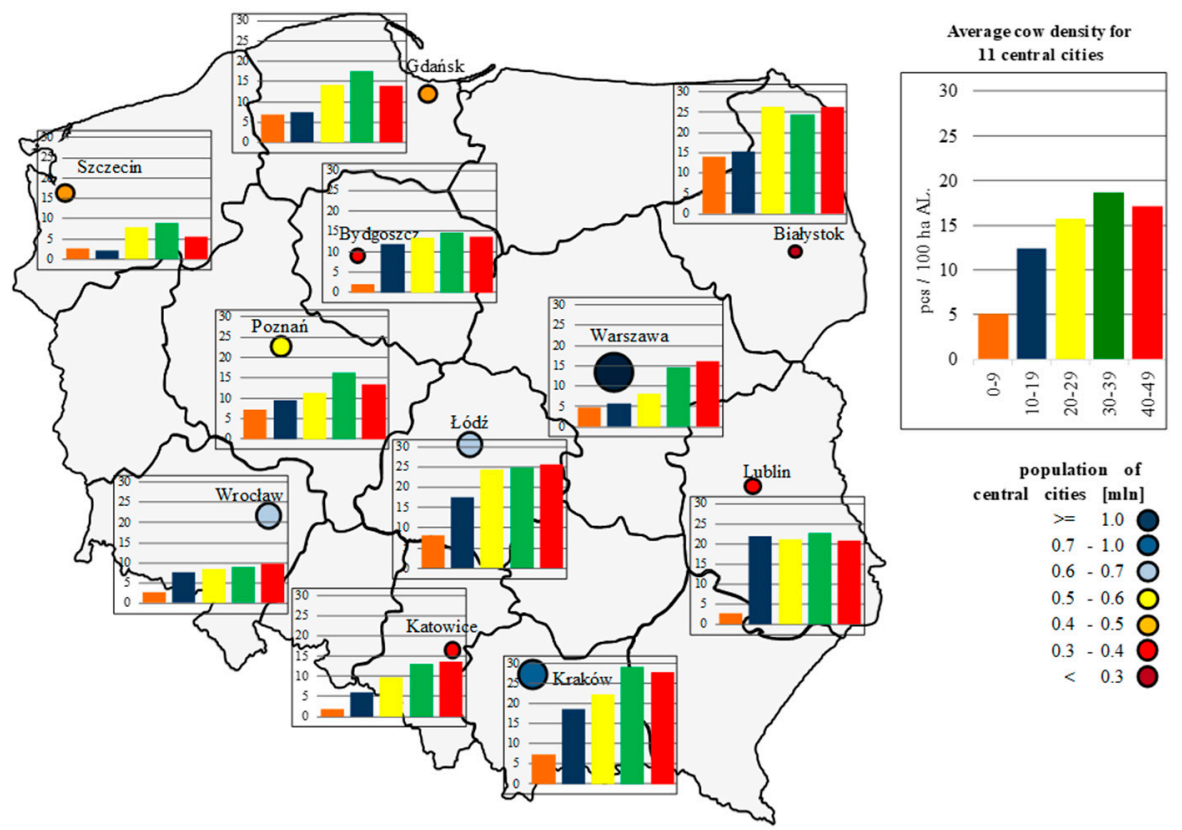

Figure 2. Cow density in Poland in 1996 for around 11 of the biggest cities in Poland (the unit and sequence of rings in voivodeships are as shown in the graph for the Polish territory). Source: own elaboration based on data [67]. 


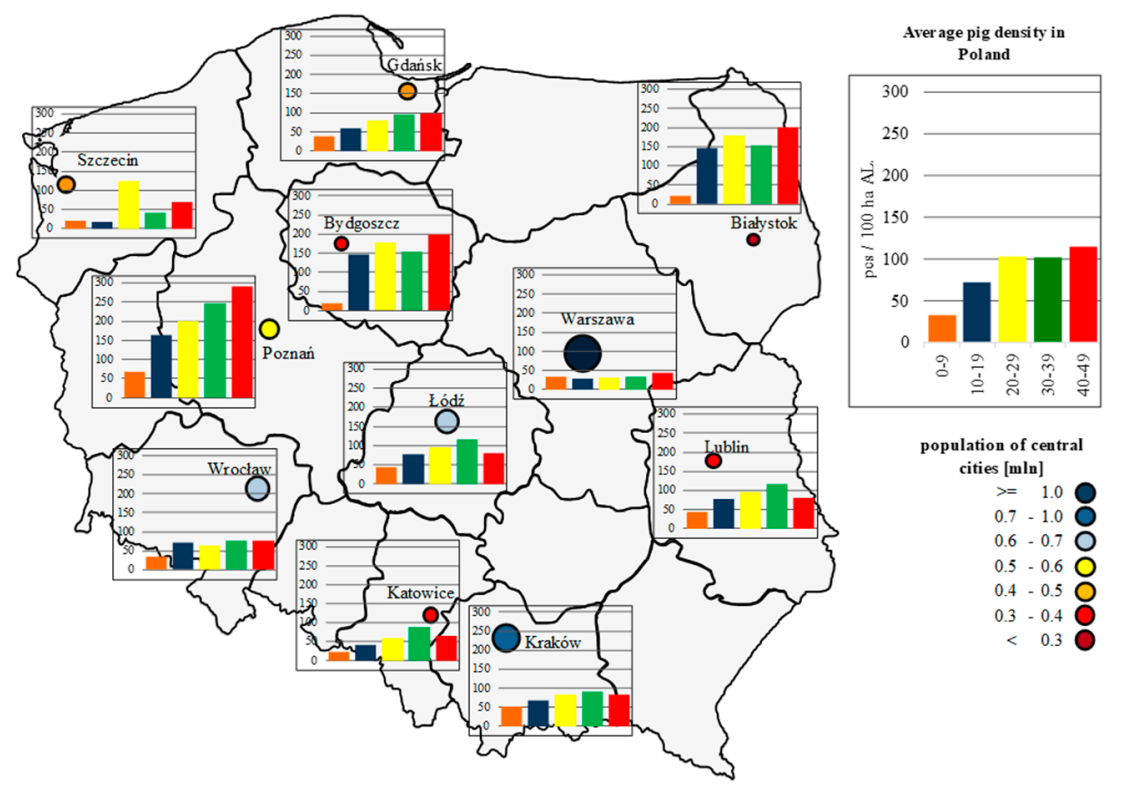

Figure 3. Pig density in Poland in 1996 for around 11 of the biggest cities in Poland (the unit and sequence of rings in voivodeships are as shown in the graph for the Polish territory). Source: own elaboration based on data [67].

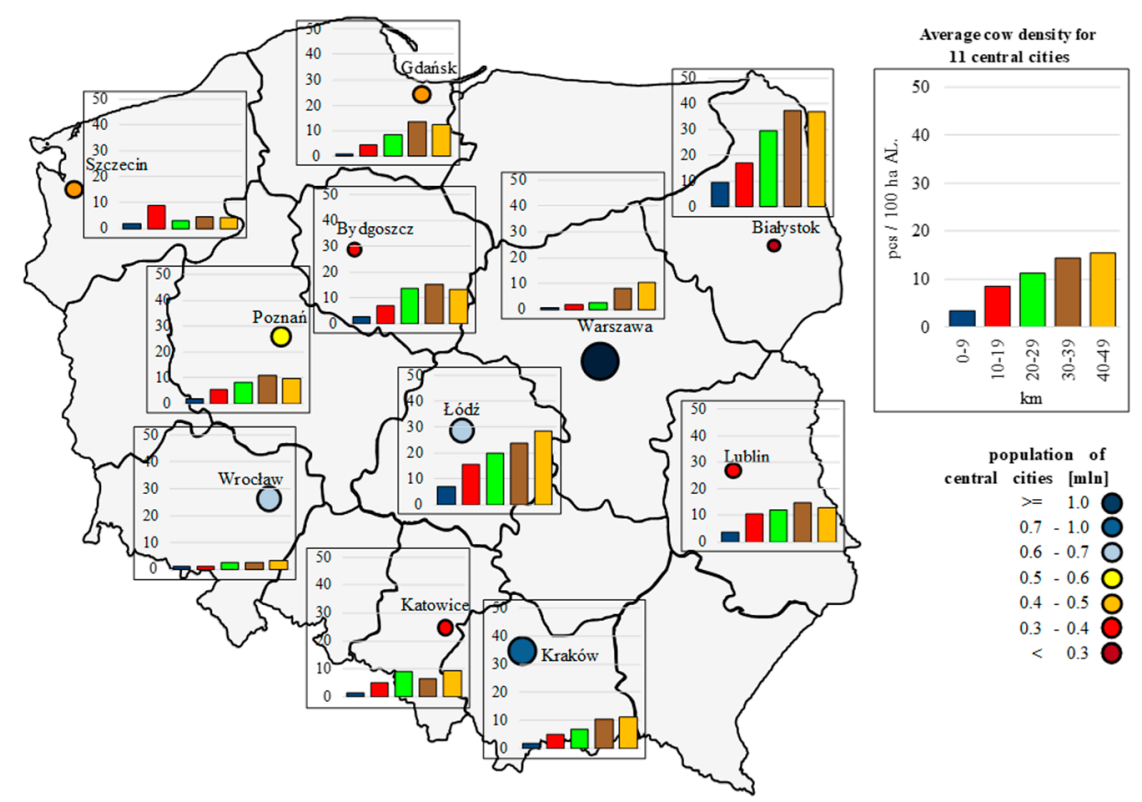

Figure 4. Cow density in Poland in 2010 for around 11 of the biggest cities in Poland (the unit and sequence of rings in voivodeships are as shown in the graph for the Polish territory). Source: own elaboration based on data [67].

Data shown in Figures 2-5 suggests that both in 1996 and 2010, in the first four rings (starting from the center), animal density increased together with the distance from the economic centers. In all the central cities covered by the study, animal density was by far the lowest in the first ring. From 1996 to 2010, there was an increase in the disproportion in animal density between the first and the second ring, and between the second and the third ring. On average, cow density in the first ring was lowered by $60 \%$ in 1996 and by $67 \%$ in 2010 . The corresponding disparities for pig density are $55 \%$ and $60 \%$, respectively. In addition, there were growing differences in animal density between the second and the third ring. In 2010, it was $26 \%$ for cows (vs. $21 \%$ in 1996) and $49 \%$ for pigs (vs. $30 \%$ in 1996). This suggests that animal production is pushed away from suburban areas located within $20 \mathrm{~km}$ from 
the centers of central cities covered by this analysis. In Warsaw, that process was witnessed within a radius of $30 \mathrm{~km}$. In the smallest cities covered by this analysis, that distance was only $10 \mathrm{~km}$.

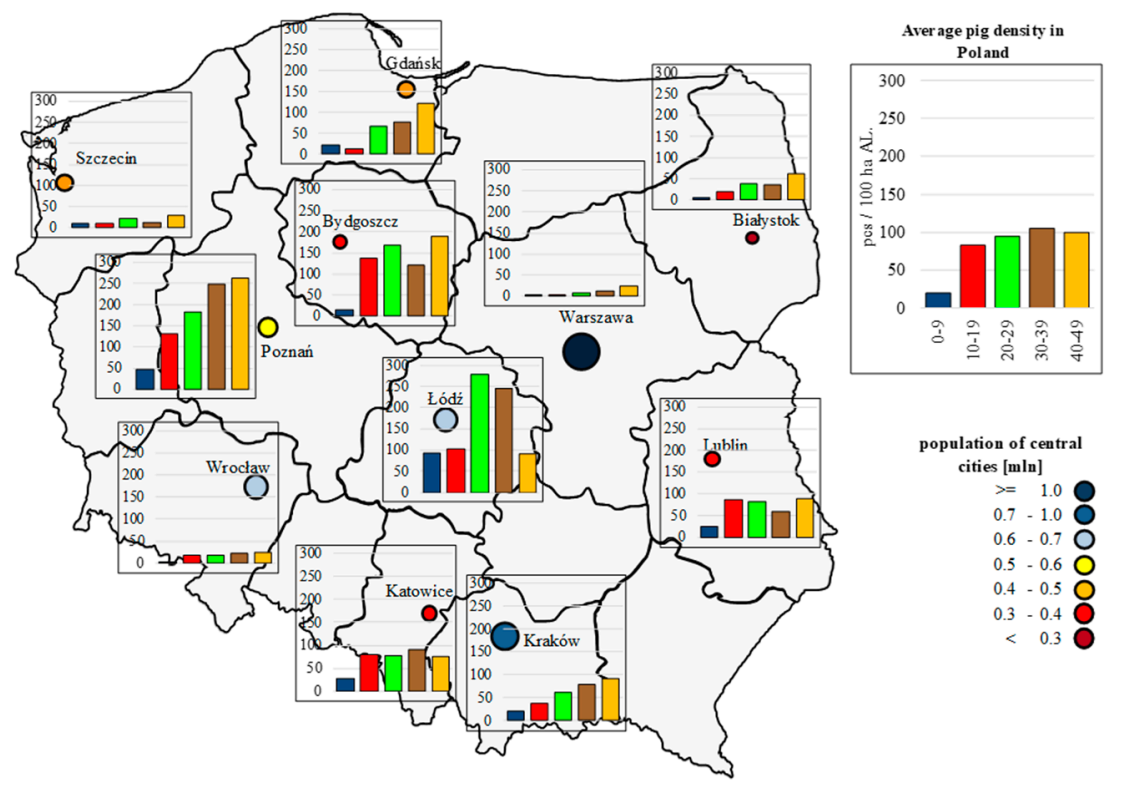

Figure 5. Pig density in Poland in 2010 for around 11 of the biggest cities in Poland (the unit and sequence of rings in voivodeships are as shown in the graph for the Polish territory). Source: own elaboration based on data [67].

Between 1996 and 2010, in absolute terms, in the first inner circle, the number of cows and pigs decreased by $84.6 \%$ and $82.2 \%$, respectively, and, in the second circle, by $54.5 \%$ and $50.6 \%$, respectively, while, in the outer ring, it decreased by $30.1 \%$ and $30.9 \%$. Similar trends were observed for Corn Belt Metropolitan Areas, where, between 1987 and 1997 in Large metro fringe counties, sales of pigs decreased by $46.9 \%$. In Nonmetro counties, depending on the counties, the groups decreased by $31.7 \%$ and $13.3 \%$. In the case of the dairy cow population, it was lowered by $11.1 \%, 1.5 \%$, and $4.4 \%$, respectively [13].

At 0.05 , both variables covered (i.e., pig and cow density) demonstrated statistically significant dependence on the distance from the city. In both cases, it can be clearly seen that, as the region's geographical distance from the city increases, so does animal density (Table 3).

Table 3. Analysis of variance of differences in animal density depending on the distance from the city.

\begin{tabular}{|c|c|c|c|c|c|c|c|c|}
\hline \multirow{2}{*}{ Description } & \multicolumn{6}{|c|}{ Distance from the City (km) } & \multirow{3}{*}{$\mathbf{F}$} & \multirow{3}{*}{$\mathbf{p}$} \\
\hline & $0-9.9$ & 10-19.9 & $20-29.9$ & $30-39.9$ & $40-49.9$ & $0-49.9$ & & \\
\hline Number & 22 & 67 & 114 & 122 & 167 & 492 & & \\
\hline $\begin{array}{l}\text { Average stock density of pig } \\
\text { population (pcs/100 ha AL) }\end{array}$ & 20.5 & 58.6 & 78.9 & 90.1 & 93.2 & 81.2 & 2.58 & 0.037 \\
\hline $\begin{array}{l}\text { Average stock density of cow } \\
\text { population (psc/100 ha AL) }\end{array}$ & 2.4 & 5.5 & 9.7 & 12.5 & 13.1 & 10.6 & 9.32 & 0.000 \\
\hline
\end{tabular}

Source: Own elaboration based on the data [67].

The regression analysis showed that the following variables proved to be significant in both models: share of cow/pig farms, average cow/pig herd size, residential housing density, and unemployment rate (Tables 4 and 5). The former had a positive relationship with the explained variable, whereas a one percentage point increase in the unemployment rate resulted in a decline in pig and cow density by 3.6 pigs per $100 \mathrm{AL}$ and 0.5 cows per $100 \mathrm{AL}$, respectively. 
Table 4. Results of regression analysis for the stocking density of the cow population.

\begin{tabular}{ccccccc}
\hline Specification & Beta & $\begin{array}{c}\text { Standard } \\
\text { Error }\end{array}$ & $\mathbf{b}$ & $\begin{array}{c}\text { Standard } \\
\text { Error }\end{array}$ & $\mathbf{t}$ & $p$ \\
\hline Constant & - & - & 5.04 & 2.249 & 2.241 & 0.026 \\
Distance from the city & -0.050 & 0.029 & -0.05 & 0.027 & -1.738 & 0.083 \\
Share of AL (\%) & -0.046 & 0.028 & -0.03 & 0.015 & -1.673 & 0.095 \\
Share of wasteland (\%) & 0.039 & 0.023 & 0.09 & 0.051 & 1.665 & 0.097 \\
Share of cow farms (\%) & 0.746 & 0.028 & 0.64 & 0.024 & 26.261 & 0.000 \\
Average cow herd size (animals) & 0.302 & 0.024 & 0.96 & 0.078 & 12.373 & 0.000 \\
Population density (people per km ${ }^{2}$ & -0.092 & 0.045 & 0.00 & 0.001 & -2.043 & 0.042 \\
Net migration rate (people per 1000 population) & -0.078 & 0.030 & -0.01 & 0.004 & -2.559 & 0.011 \\
Residential housing density (buildings per km ${ }^{2}$ ) & 0.180 & 0.042 & 0.03 & 0.008 & 4.325 & 0.000 \\
Unemployment (\%) & -0.119 & 0.025 & -0.49 & 0.103 & -4.736 & 0.000 \\
Entrepreneurship (companies per 10,000 population) & -0.154 & 0.038 & -0.01 & 0.001 & -4.064 & 0.000 \\
Own income of municipalities (PLN thousand per capita) & 0.054 & 0.031 & 0.78 & 0.441 & 1.775 & 0.076 \\
\hline
\end{tabular}

$\mathrm{R}^{2}=0.792, \mathrm{~F}=166.45, p<0.0000$. Source: Own elaboration based on the data [67].

Table 5. Results of regression analysis for the stocking density of the pig population.

\begin{tabular}{ccccccc}
\hline Specification & Beta & $\begin{array}{c}\text { Standard } \\
\text { Error }\end{array}$ & $\mathbf{b}$ & $\begin{array}{c}\text { Standard } \\
\text { Error }\end{array}$ & $\mathbf{t}$ & $p$ \\
\hline Constant & - & - & 3.92 & 27.623 & 0.142 & 0.887 \\
Distance from the city & -0.048 & 0.035 & -0.47 & 0.351 & -1.348 & 0.178 \\
Share of AL (\%) & 0.016 & 0.035 & 0.09 & 0.196 & 0.449 & 0.654 \\
Share of wasteland (\%) & 0.024 & 0.029 & 0.54 & 0.664 & 0.814 & 0.416 \\
Share of pig farms (\%) & 0.441 & 0.035 & 3.63 & 0.292 & 12.417 & 0.000 \\
Average pig herd size (animals) & 0.568 & 0.029 & 1.59 & 0.083 & 19.263 & 0.000 \\
Population density (people per km (2) $_{\text {Net migration rate (people per 1000 population) }}$ & -0.085 & -0.067 & -0.02 & 0.010 & -1.521 & 0.129 \\
Residential housing density (buildings per km ${ }^{2}$ ) & 0.128 & 0.038 & -0.10 & 0.056 & -1.774 & 0.077 \\
Unemployment (\%) & -0.086 & 0.031 & -3.65 & 1.304 & -2.800 & 0.005 \\
Entrepreneurship (companies per 10,000 population) & -0.041 & 0.046 & -0.01 & 0.016 & -0.883 & 0.378 \\
Own income of municipalities (PLN thousand per capita) & 0.027 & 0.038 & 4.02 & 5.607 & 0.717 & 0.474 \\
\hline
\end{tabular}

$\mathrm{R}^{2}=0.681, \mathrm{~F}=93.491, p<0.0000$. Source: Own elaboration based on the data [67].

The explained and explanatory variables used in the correlation analysis are highly volatile irrespective of the ring concerned (Table 6). The smallest variation was found in unemployment levels and in the personal incomes of municipalities. The conclusion regarding the explanatory variables is that, as the distance from the central city increases, so does the share of cow farms, the share of pig farms, and unemployment. Conversely, population density, residential buildings' density, and entrepreneurship levels decline as the distance from the central city increases. From 2001 to 2010, the highest net migration rate was recorded in areas located within 10 to $19 \mathrm{~km}$ away from the center, and decreased as the distance from the central city increased, becoming negative ( -4.5 persons per 1.000 population) in the last ring. The net migration rate in the first ring was balanced. However, it was positive for the three biggest cities and Białystok, and negative for other cities.

The impact analysis of the selected factors on pig and cow density demonstrated that, throughout the study area, they had a strong or extremely strong positive correlation only with the share of farms keeping the animal species concerned and with average animal numbers (Table 7). With regard to other variables, a weak correlation was found between most factors and cow density. In the case of pig density, a weak correlation existed only with unemployment and a net migration rate. This was due to unemployment levels being relatively stable in all rings, and to the net migration rate being negative in the first ring (with the lowest pig density) and reaching the peak level in the second ring (with a much higher animal density) of most central cities. In turn, a moderate correlation was found between pig density and entrepreneurship levels. Other variables were concluded to be poorly correlated with pig density. 
Table 6. Characteristics of variables for areas located around 11 of Poland's biggest cities in 2010.

\begin{tabular}{|c|c|c|c|c|c|c|c|c|c|c|c|c|c|c|c|}
\hline & 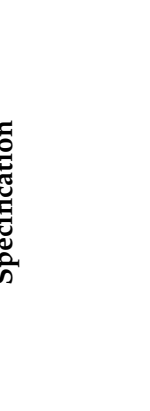 & 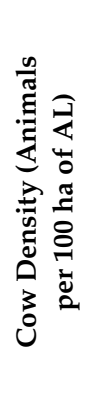 & 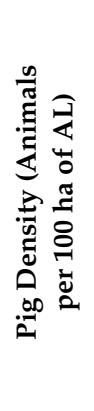 & 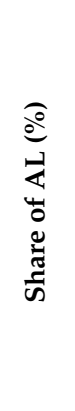 & 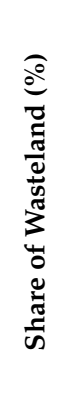 & 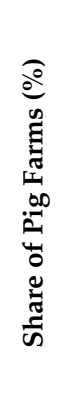 & 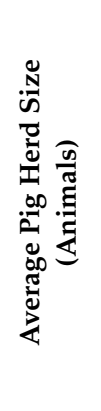 & 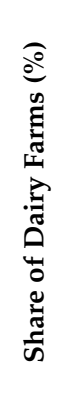 & 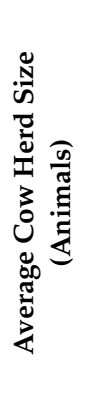 & 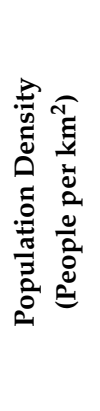 & 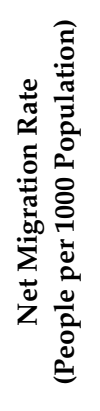 & 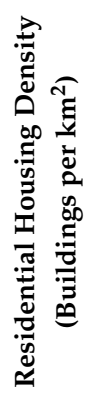 & 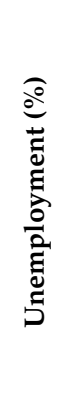 & 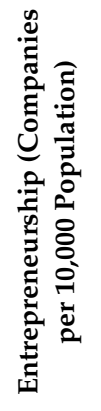 & 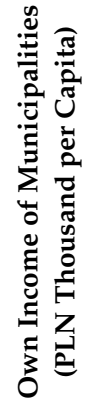 \\
\hline \multirow{4}{*}{$0-9 \mathrm{~km}$} & Min & 0.0 & 0.0 & 10.3 & 0.0 & 0.0 & 0.0 & 0.0 & 0.0 & 102 & -45.1 & 11.0 & 2.4 & 753 & 1.3 \\
\hline & Max & 11.5 & 94.1 & 83.4 & 19.2 & 22.9 & 88.0 & 22.5 & 24.1 & 4005 & 335.5 & 357.5 & 8.8 & 2025 & 4.9 \\
\hline & Avg & 3.4 & 19.2 & 28.2 & 8.3 & 5.2 & 22.7 & 3.4 & 4.7 & 2034 & -0.3 & 121.1 & 5.6 & 1538 & 2.3 \\
\hline & Std. dev. & 3.2 & 27.3 & 17.3 & 5.6 & 5.5 & 21.2 & 4.9 & 5.1 & 1088 & 105.8 & 70.0 & 1.9 & 296 & 0.9 \\
\hline \multirow{4}{*}{$10-19 \mathrm{~km}$} & Min & 0.0 & 0.0 & 3.2 & 0.0 & 0.0 & 0.0 & 0.0 & 0.0 & 27 & -59.5 & 8.9 & 2.0 & 590 & 0.8 \\
\hline & Max & 26.8 & 296.1 & 90.7 & 35.6 & 35.2 & 150.7 & 30.5 & 22.2 & 3988 & 445.1 & 564.8 & 10.9 & 2150 & 6.4 \\
\hline & Avg & 8.3 & 83.0 & 44.8 & 3.9 & 12.2 & 29.1 & 10.6 & 4.8 & 327 & 62.6 & 49.3 & 5.4 & 1143 & 2.0 \\
\hline & Std. dev. & 6.3 & 72.2 & 24.6 & 7.1 & 9.5 & 28.4 & 7.7 & 3.8 & 831 & 111.4 & 96.5 & 2.2 & 371 & 1.0 \\
\hline \multirow{4}{*}{$20-29 \mathrm{~km}$} & Min & 0.0 & 0.0 & 3.6 & 0.0 & 0.0 & 0.0 & 0.0 & 0.0 & 25 & -85.4 & 3.4 & 2.0 & 372 & 0.5 \\
\hline & Max & 55.1 & 1653.8 & 94.2 & 27.3 & 57.7 & 403.3 & 56.7 & 13.9 & 3946 & 368.0 & 406.0 & 12.3 & 2223 & 4.6 \\
\hline & Avg & 11.3 & 94.9 & 51.3 & 3.1 & 17.4 & 41.2 & 15.4 & 5.1 & 203 & 31.8 & 32.2 & 5.9 & 1081 & 1.6 \\
\hline & Std. dev. & 9.3 & 162.3 & 22.0 & 4.6 & 12.5 & 45.9 & 11.9 & 3.2 & 537 & 83.1 & 62.1 & 2.3 & 349 & 0.8 \\
\hline \multirow{4}{*}{$30-39 \mathrm{~km}$} & Min & 0.0 & 0.0 & 9.8 & 0.0 & 0.0 & 0.0 & 0.0 & 0.0 & 13 & -86.2 & 5.7 & 2.0 & 318 & 0.3 \\
\hline & Max & 66.1 & 898.0 & 96.0 & 39.4 & 55.2 & 150.5 & 57.1 & 16.4 & 1769 & 220.0 & 217.8 & 14.6 & 1393 & 4.2 \\
\hline & Avg & 14.3 & 105.4 & 54.9 & 2.5 & 20.4 & 35.1 & 20.1 & 4.9 & 123 & 17.2 & 23.6 & 7.1 & 902 & 1.2 \\
\hline & Std. dev. & 11.7 & 129.7 & 18.5 & 5.8 & 14.6 & 29.0 & 13.4 & 3.6 & 270 & 52.6 & 29.7 & 2.5 & 247 & 0.6 \\
\hline \multirow{4}{*}{$40-49 \mathrm{~km}$} & Min & 0.0 & 0.0 & 7.5 & 0.0 & 0.0 & 0.0 & 0.0 & 0.0 & 9 & -92.6 & 1.9 & 3.0 & 321 & 0.4 \\
\hline & Max & 77.9 & 425.6 & 96.1 & 37.8 & 62.5 & 635.9 & 69.4 & 17.1 & 2983 & 196.0 & 369.2 & 20.1 & 1429 & 6.5 \\
\hline & Avg & 15.4 & 99.9 & 56.4 & 2.1 & 23.1 & 38.1 & 22.6 & 5.9 & 111 & -4.5 & 18.5 & 8.4 & 887 & 1.2 \\
\hline & Std. dev. & 14.2 & 99.2 & 18.4 & 4.0 & 16.0 & 54.9 & 14.6 & 3.7 & 499 & 43.3 & 41.5 & 3.0 & 233 & 0.7 \\
\hline \multirow{4}{*}{$0-49 \mathrm{~km}$} & Min & 0.0 & 0.0 & 3.2 & 0.0 & 0.0 & 0.0 & 0.0 & 0.0 & 9 & -92.6 & 1.9 & 2.0 & 318 & 0.3 \\
\hline & Max & 77.9 & 1653.8 & 96.1 & 39.4 & 62.5 & 635.9 & 69.4 & 24.1 & 4005 & 445.1 & 564.8 & 20.1 & 2223 & 6.5 \\
\hline & Avg & 13.2 & 95.8 & 51.8 & 2.8 & 19.0 & 37.0 & 18.0 & 5.3 & 282 & 14.0 & 32.7 & 7.0 & 1256 & 1.4 \\
\hline & Std. dev. & 11.7 & 121.1 & 21.5 & 5.3 & 14.7 & 43.2 & 13.6 & 3.7 & 673 & 82.0 & 62.4 & 2.8 & 342 & 0.8 \\
\hline
\end{tabular}

Source: own study based on [67] data. 
Table 7. Correlation coefficients between pig and cow density, on the one side, and selected explanatory variables, on the other side, in function of the distance from the central city.

\begin{tabular}{|c|c|c|c|c|c|c|c|c|c|c|c|}
\hline 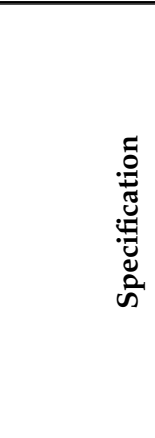 & & 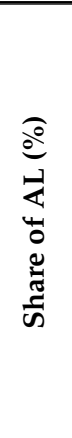 & 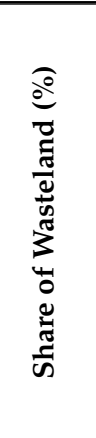 & 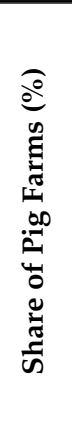 & 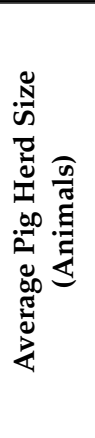 & 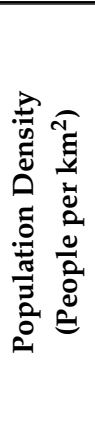 & 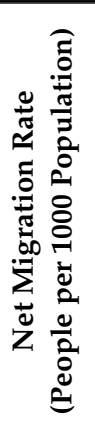 & 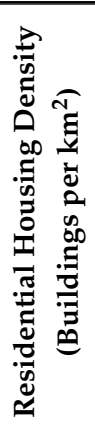 & 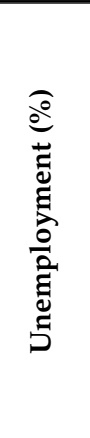 & 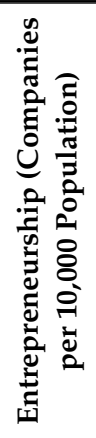 & 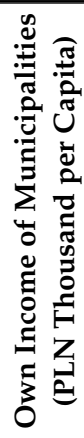 \\
\hline 0-9 km & & 0.10 & -0.11 & 0.75 & 0.56 & -0.24 & -0.03 & -0.24 & -0.20 & 0.09 & 0.18 \\
\hline $10-19 \mathrm{~km}$ & 吾充 & 0.08 & -0.40 & 0.74 & 0.82 & -0.09 & 0.06 & -0.19 & -0.10 & -0.16 & -0.01 \\
\hline $20-29 \mathrm{~km}$ & $\overrightarrow{\tilde{g}} \Xi$ & 0.11 & -0.17 & 0.46 & 0.87 & -0.09 & -0.06 & -0.15 & 0.01 & -0.04 & -0.05 \\
\hline $30-39 \mathrm{~km}$ & ¿ 8 & 0.26 & -0.20 & 0.69 & 0.85 & -0.14 & -0.12 & -0.17 & -0.12 & -0.10 & -0.11 \\
\hline $40-49 \mathrm{~km}$ & $.00 \bar{D}$ & 0.23 & -0.31 & 0.79 & 0.66 & -0.12 & -0.14 & -0.18 & -0.04 & -0.14 & -0.12 \\
\hline $0-49$ km & & 0.21 & -0.24 & 0.63 & 0.73 & -0.15 & -0.10 & -0.19 & 0.00 & -0.14 & -0.12 \\
\hline 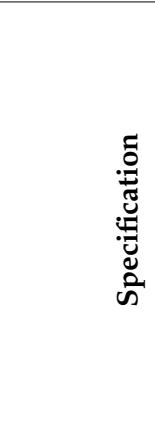 & & 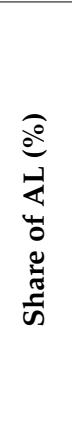 & 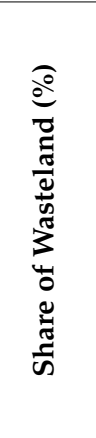 & 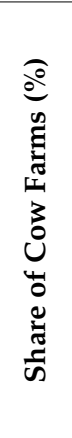 & 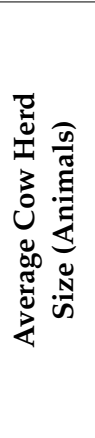 & 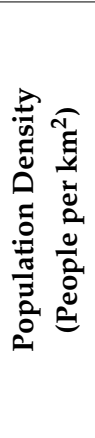 & 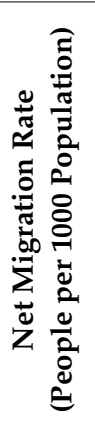 & 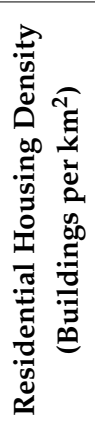 & 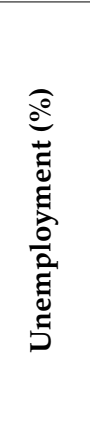 & 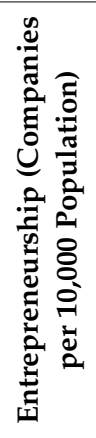 & 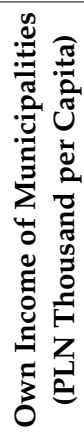 \\
\hline 0-9 km & & 0.04 & -0.04 & 0.73 & 0.69 & -0.21 & 0.29 & -0.12 & 0.31 & -0.05 & -0.06 \\
\hline $10-19 \mathrm{~km}$ & & 0.24 & -0.21 & 0.88 & 0.53 & -0.34 & 0.04 & -0.36 & 0.42 & -0.40 & -0.32 \\
\hline $20-29 \mathrm{~km}$ & ప్తి త్తి & 0.16 & -0.24 & 0.81 & 0.56 & -0.21 & -0.12 & -0.32 & 0.32 & -0.47 & -0.31 \\
\hline $30-39 \mathrm{~km}$ & 78 & 0.31 & -0.26 & 0.81 & 0.56 & -0.25 & -0.29 & -0.29 & 0.09 & -0.41 & -0.33 \\
\hline $40-49 \mathrm{~km}$ & $0 \frac{3}{5}$ & 0.19 & -0.25 & 0.84 & 0.65 & -0.25 & -0.14 & -0.25 & -0.20 & -0.44 & -0.16 \\
\hline $0-49 \mathrm{~km}$ & 0 & 0.27 & -0.26 & 0.84 & 0.58 & -0.29 & -0.20 & -0.32 & 0.10 & -0.46 & -0.31 \\
\hline
\end{tabular}

For most variables, correlation coefficients calculated for rings 2 to 5 were close to the level calculated for the entire study area. Conversely, in the central ring of metropolitan areas, correlation coefficients calculated for both cow density and pig density largely differed from what was found in other rings. This can be explained by the very significant differences between central cities themselves, and the considerable heterogeneity in cow and pig density in central cities. Additionally, these rings included the smallest number of municipalities (only 22).

\section{Discussion}

As shown by this analysis, as the distance from the economic center increases, cow and pig density per 100 ha of agricultural land also increases. Similar trends are true for the share of agricultural land in total land area, and, therefore, the disproportions in the concentration of animal production between central areas and remote rings are even stronger. This reflects the marginalization of production activities both in urban and suburban areas.

Research on livestock concentration in suburban areas was carried out in the 1970s and 1980s, mainly in economically developed countries, and demonstrated that traditional animal production is the first activity to be discontinued (though not entirely) in the immediate vicinity of metropolitan areas $[14,15,82-84]$. In Poland, due to historical events, these processes started with a delay. However, 
these findings suggest that animal depopulation in suburban areas is progressing and has already reached an advanced stage. Typical agricultural production is often replaced with hobbyist production, horticulture, special crops, and agritourism where one of the attractions are horses [15,52,85-87]. An example is the study of five sub-metropolitan counties in California including four of the most important products produced by local agriculture that are presented. In 1950, four of them had at least two animal products, while, in 2001, only two counties had one animal product (Alameda had cattle in third place and San Diego had egg production in fourth place). Fruit and vegetable production and the nursery sector gained the most importance [86]. The concentration processes of these production activities in suburban areas of Polish metropolises have not yet been completed, and, therefore, relevant research needs to be carried out.

One of the main reasons why animal production is discontinued could be what is referred to as the instability syndrome [14], manifested by a deterioration in long-term prospects for suburban agriculture, which is noticeable to farmers. This includes the expected decline in agricultural land resources and the resulting reduction in the feed production potential, which is an aspect that is of particular importance to cattle production and of minor importance to pig production. That process is also experienced in Poland because the decline in agricultural land within $25 \mathrm{~km}$ of the center of Poland's biggest cities is much greater than the national average figure [5]. In addition to the growing suburban population, this is also driven by rapid growth in Polish GDP, which requires plants to be extended and land to be allocated for warehousing and logistic facilities. Such constructions are mostly located in the outskirts of the biggest cities [25,88-90], primarily because of the demand for open spaces at lower prices [91-93]. In Poland, the low degree of saturation with such modern infrastructure has been and will be among the major factors affecting the conversion of agricultural land. The instability syndrome also reduces investments due to their capital intensity and long payback periods. This is especially true for construction investments, which are necessary for the development of animal production. Additionally, this results in suburban farmers becoming less interested in subsidies and direct payments [20].

In light of literature, another aspect of importance in Polish realities is the considerable fragmentation and the related poor profitability of agricultural undertakings. Farmers who earn little from their farms will be inclined to sell their land and reallocate it for non-agricultural uses [45,94-98]. Therefore, intensification, proposed as a method for responding to urban expansion in Polish realities, is not likely to be adopted by more than a few producers (though not necessarily endlessly) [48]. Therefore, as suburban areas expand, a rapid decline in agricultural land can be expected, which is followed by a reduction in animal stocks. In Central and Eastern European countries, it was observed that suburban land subject to speculative transactions becomes wasteland. Usually, this results in a total and permanent discontinuation of production activities. For example, in the sub-metropolitan area of Bucharest, $85 \%$ of the land used for development in 2010-2013 was excluded from agricultural production for at least three years, whereas, in 2002-2005, it was only 35\% [94]. This is also encouraged by the increasing population density and migration [3]. These conclusions are confirmed in the three biggest central cities covered by this analysis. In turn, the small share of wasteland around Poznań and Łódź corroborates research, which found that discontinuation of agricultural production and land use is less frequent in regions with intensive land cultivation and with high intensity and high productivity of agricultural land [99-102]. Cities located in regions with the best agricultural land (Lublin, Wrocław) had a medium level of wasteland. This is encouraged by the regulations for agricultural land protection, as applicable in Poland. Top-quality agricultural land can be reallocated for non-agricultural uses upon completing a lengthy procedure, and only if agreed by the Ministry of Agriculture and Rural Development. The related fees are very expensive (can go beyond EUR 100,000 per hectare) [1,21].

In turn, environmental and neighborhood aspects (usually underestimated by Polish farmers) will grow in importance. Until the mid-1990s, due to most farms being engaged in multiple production activities and because of the small scale of suburban settlement, neighborhood conflicts were virtually non-existent. However, in accordance with the literature, it can be expected that, as urban areas enter 
the agricultural activity zone, economic pressures as well as conflicts of interests will increase [48]. The economic realities require that farmers who intend to continue their agricultural production not only increase their production scale but also shift to more intensive production schemes, which results in growing agricultural nuisances. In the case of animal production, increasingly larger buffer distances will be required. However, due to demand for suburban development, these measures may become ineffective. Most urban residents who want to settle in the countryside are increasingly out of touch with the agricultural reality. This makes it difficult, if not impossible, for them to fully realize the probable intensity of externalities, even if they are informed of nearby agricultural activities when purchasing their property. However, this does not protect the farmers from complaints about the nuisances. Research confirms that, as the physical and social distance from agriculture grows, so do the concerns about the impacts of agricultural production on the environment (especially water) and its pollution, the concerns about animal welfare, and the fear of adverse consequences of agricultural production for the quality of life for the residents [103-111]. These concerns can be limited in various ways, including through direct communication and frequent social meetings between farmers and non-farmers [112-114]. The farmers' adaptability to gradual social changes resulting from the inflow of the rural population, and from a shift in how environmental protection is perceived, which strictly depends on how much they are attached to where they live and how much they are involved in the local community $[115,116]$. In turn, a generations-long tradition of local agricultural production, combined with the risk of losing one's farming identity, considerably reduces the farmers' adaptability $[117,118]$. The proportions between these farming groups largely affect the quality of the natural environmental and the level of environmental services available in agricultural production areas.

The pace of the shift to non-agricultural activities will also depend on legal conditions. The caveat emptor (let the buyer beware) principle, as applicable in North America, could reduce the number of complaints about agricultural investments and related externalities [87,119]. In addition, it is highly difficult to determine the inconvenience posed by odors because no standard precise methods for odor measurement have been implemented yet [11]. In 2019, the Polish parliament proposed another draft of what is referred to as the Odor Act. However, it did not include any standards for odors and was limited to the proposed minimum distance of a planned agricultural undertaking [120]. Another proposition that secures the long-term development potential of agricultural production could be to establish farming zones with limited settlement options and a restricted ability to complain about nuisance [69].

\section{Conclusions}

This study confirmed the first hypothesis, which states that the greater distance from central cities is the cow and pig density increases. A similar trend was observed concerning the share of agricultural land in the total area of land. The lowest livestock density was recorded in the two inner rings. From 1996 to 2010, the gap between these rings and the livestock density levels recorded in other rings increased. Another finding is that the size of the central city has an impact on the distance from the center at which the livestock density becomes close to the average figure for the voivodeship where the central city is located. In the case of Warsaw, that distance was beyond the study area, i.e., over $50 \mathrm{~km}$.

In turn, the second hypothesis was not confirmed. The study only corroborated the high correlation between livestock (cow and pig) density and the share of corresponding livestock farms in the total number of farms and the average herd size. With regard to other agricultural and socioeconomic factors, the correlation was weak or low, except for the correlation between the entrepreneurship indicator and pig density. The regression analysis demonstrated that the share of cow and pig farms in the total number of farms, average herd size, residential housing density, and unemployment rate had a significant impact on the density of animal groups considered.

Funding: The APC was funded by Poznan University of Life Sciences.

Conflicts of Interest: The author declares no conflict of interest. 


\section{References}

1. Sroka, W.; Mikołajczyk, J.; Wojewodzic, T.; Kwoczyńska, B. Agricultural Land vs. Urbanisation in Chosen Polish Metropolitan Areas: A Spatial Analysis Based on Regression Trees. Sustainability 2018, $10,837$. [CrossRef]

2. Kizos, T.; Tsilimigkas, G.; Karampela, S. What Drives Built-Up Area Expansion on Islands? Using Soil Sealing Indicators to Estimate Built-Up Area Patterns on Aegean Islands, Greece. Tijdschr. Econ. Soc. Geogr. 2017, 108, 703-886. [CrossRef]

3. Zasada, I. Multifunctional peri-urban agriculture-A review of societal demands and the provision of goods and services by farming. Land Use Policy 2011, 28, 639-648. [CrossRef]

4. Lovell, S.T. Multifunctional Urban Agriculture for Sustainable Land Use Planning in the United States. Sustainability 2010, 2, 2499-2522. [CrossRef]

5. Pepliński, B. Determinanty Regionalnych Zmian w Sektorze Produkcji Trzody Chlewnej w Polsce; Wydawnictwo Uniwersytetu Przyrodniczego: Poznań, Poland, 2019; ISBN 978-83-7160-926-8.

6. Sinclair, R. Von Thünen and urban sprawl. Ann. Assoc. Am. Geogr. 1967, 57, 72-87. [CrossRef]

7. Kupkova, L. Suburbanization and urbanization of Prague-The theory of zonal models and reality. In Modelling Natural Environment and Society: Geographical Systems and Risk Processes; Dostal, P., Langhammer, J., Eds.; Prague Charles University: Prague, Czech Republic, 2007; pp. 205-225.

8. Siekierski, J. Ład przestrzenny i lokalizacja w teorii ekonomii a konkurencyjność regionów. Rocz. Nauk. Stowarzyszenia Ekon. Rolnictwa Agrobiznesu 2008, 10, 234-239.

9. Dye, S.; Bermudez, N.; Coyle, J. The Rap Sheet on Animal Factories; Sierra Club: San Francisco, CA, USA, 2002.

10. Guttmann, J.P. Agricultural Land-Use Change and Local Context: The Shenandoah-Cumberland Valley Apple-Growing District in the Eastern United States. Ph.D. Thesis, University of Tennessee, Knoxville, TN, USA, 2012. Available online: https://trace.tennessee.edu/utk_graddiss/1456 (accessed on 2 September 2017).

11. Henderson, S.R. Managing land-use conflict around urban centres: Australian poultry farmer attitudes towards relocation. Appl. Geogr. 2005, 25, 97-119. [CrossRef]

12. Sharp, J.S.; Tucker, M. Awareness and Concern about Large-Scale Livestock and Poultry: Results from a Statewide Survey of Ohioans. Rural Sociol. 2005, 70, 208-228. [CrossRef]

13. Sharp, J.S.; Roe, B.; Irwin, E.G. The Changing Scale of Livestock Production in and around Corn Belt Metropolitan Areas, 1978 to 1997. Growth Change 2002, 33, 115-132. [CrossRef]

14. Berry, D. Sensitivity of dairying to urbanisation: A study of Northeastern Illinois. Prof. Geogr. 1979, 31, 170-176. [CrossRef]

15. Lawrence, H.W. Changes in agricultural production in metropolitan areas. Prof. Geogr. 1988, 40, $159-175$. [CrossRef]

16. Ilbery, B.; Bowler, I. From agricultural productivism to post-productivism. In The Geography of Rural Change; Ilbery, B., Ed.; Addison Wesley Longman: Harlow, UK, 1998; pp. 57-84.

17. Badach, E.; Cymanow, P. Impact of agglomerations on social, agricultural and environmental transformations of neighbouring municipalities. Ann. PAAAE 2019, 21, 24-35. [CrossRef]

18. Busko, M.; Szafranska, B. Analysis of Changes in Land Use Patterns Pursuant to the Conversion of Agricultural Land to Non-Agricultural Use in the Context of the Sustainable Development of the Malopolska Region. Sustainability 2018, 10, 136. [CrossRef]

19. Nalej, M. Agricultural land cover changes in metropolitan areas of Poland for the period 1990-2012. Misc. Geogr. 2016, 20, 39-45. [CrossRef]

20. Sroka, W. Resources and use of agricultural land in Polish cities according to chosen theories of location of agricultural production. Acta Sci. Pol. Oecon. 2015, 14, 135-147.

21. Krzyk, P.; Tokarczuk, T.; Heczko-Hyłowa, E.; Ziobrowski, Z. Obszary Rolne Jako Element Struktury Przestrzennej Miast_Problemy Planistyczne; Instytut Rozwoju Miast: Krakow, Poland, 2013; pp. 48-69. ISBN 978-83-89440-72-3.

22. Huang, D.; Jin, H.; Zhao, X.; Liu, S. Factors influencing the conversion of arable land to urban use and policy implications in Beijing, China. Sustainability 2015, 7, 180-194. [CrossRef]

23. Deng, X.; Huang, J.; Rozelle, S.; Zhang, J.; Li, Z. Impact of urbanization on cultivated land changes in China. Land Use Policy 2015, 45, 1-7. [CrossRef] 
24. Zasada, I.; Fertner, C.; Piorr, A.; Nielsen, T.S. Peri-urbanisation and multifunctional adaptation of agriculture around Copenhagen. Dan. J. Geogr. 2011, 111, 59-72. [CrossRef]

25. Ravetz, J.; Fertner, C.; Nielsen, T.S. The dynamics of peri-urbanization. In Peri-Urban Futures: Scenarios and Models for Land Use Change in Europe; Springer: Berlin/Heidelberg, Germany, 2013; pp. 13-44. ISBN 978-3-642-30528-3.

26. Fujita, M. The evolution of spatial economics: From Thünen to the New Economic Geography. Jpn. Econ. Rev. 2010, 61, 1-32. [CrossRef]

27. Kellerman, A. Agricultural location theory, 2: Relaxation of assumptions and applications. Environ. Plan. A 1989, 21, 1427-1446. [CrossRef]

28. Ponsard, C. Historie des Theories Economiques Spatiales; A. Colin: Paris, France, 1958.

29. Rokicki, T. Determinanty ZróżNicowania i Relokalizacji Produkcji Owczarskiej w Unii Europejskiej; SGGW: Warszawa, Poland, 2017.

30. Fontes, F.; Palmer, C. "Land Sparing" in a von Thünen Framework: Theory and Evidence from Brazil. Land Econ. 2018, 94, 556-576. [CrossRef]

31. Boori, M.S.; Vozenilek, V.; Choudhary, K. Land use cover disturbance due to tourism in Jeseníky Mountain. Egypt. J. Remote Sens. Space Sci. 2015, 18, 17-26.

32. Chaplin, J.; Brabyn, L. Using remote sensing and GIS to investigate the impacts of tourism on forest cover in the Annapurna Conservation Area, Nepal. Appl. Geogr. 2013, 43, 159-168. [CrossRef]

33. Folefack, A.J.J.; Adamowski, J.F. Application of the Von Thünen Model in Determining Optimal Locations to Transport Compost for Crop Production Outside of Yaoundé, Cameroon. J. Hum. Ecol. 2012, 39, 125-143. [CrossRef]

34. Filatova, T. Empirical agent-based land market: Integrating adaptive economic behavior in urban land-use models. Comput. Environ. Urban. Syst. 2015, 54, 397-413. [CrossRef]

35. Parker, D.C.; Brown, D.G.; Filatova, T.; Riolo, R.; Robinson, D.T.; Sun, S. Do land markets matter? A modeling ontology and experimental design to test the effects of land markets for an agent-based model of Ex-urban residential land-use change. In Models of Geographical Systems; Heppenstall, A., Crooks, A., See, L., Batty, M., Eds.; Springer: Dordrecht, The Netherlands, 2012; pp. 525-542.

36. Irwin, E.G. New directions for urban economic models of land use change: Incorporating spatial dynamics and heterogeneity. J. Reg. Sci. 2010, 50, 65-91. [CrossRef]

37. Angelsen, A. Forest Cover Change in Space and Time: Combining the Von Thünen and Forest Transition Theories; World Bank Policy Research Working Paper 4117; World Bank: Washington, DC, USA, 2007.

38. Walker, R. Theorizing land-cover and land-use change: The case of tropical deforestation. Int. Reg. Sci. Rev. 2004, 27, 247-270. [CrossRef]

39. Bockstael, N.E.; Irwin, E.G. Economics and the land use-environment link. In The International Yearbook of Environmental and Resource Economics 1999/2000; Folmer, H., Tietenberg, T., Eds.; Edward Elgar Publishing: Northampton, MA, USA, 2000; pp. 1-54.

40. Clark, T.N.; Lloyd, R.; Wong, K.K.; Jain, P. Amenities drive urban growth. J. Urban Aff. 2002, 24, $493-515$. [CrossRef]

41. Jager, J. Urban land rent theory: A regulationist perspective. Int. J. Urban Reg. Res. 2003, 27, $233-249$. [CrossRef]

42. Wigier, M. Czas i przestrzeń w długookresowym rozwoju rolnictwa i obszarów wiejskich-Ujęcie retrospektywne. J. Agribus. Rural Dev. 2012, 24, 263-272. [CrossRef]

43. $\mathrm{Xu}, \mathrm{W}$. The Changing Dynamics of Land-Use Change in Rural China A Case Study of Yuhang, Zhejiang Province. Environ. Plan. A 2004, 36, 1595-1615. [CrossRef]

44. Kikuchi, T.; Ranaweerage, E. Research perspectives and methods on the changes of agricultural land use in metropolitan areas. Geogr. Rep. Tokyo Metrop. Univ. 2015, 50, 117-126.

45. Wästfelt, A.; Zhang, Q. Reclaiming localisation for revitalising agriculture: A case study of peri-urban agricultural change in Gothenburg, Sweden. J. Rural Stud. 2016, 47, 172-185. [CrossRef]

46. Libby, L.W.; Stewart, P.A. The Economics of Farmland Conversion. In Under the Blade: The Conversion of Agricultural Landscapes; Olson, R.H., Lyson, T.A., Eds.; Westview Press: Boulder, CO, USA, 1999.

47. Bunce, M.F. Agricultural Land as a Real Estate Commodity: Implications for Farmland Preservation in the North American Urban Fringe. Landsc. Plan. 1985, 12, 177-192. [CrossRef] 
48. Bryant, C.R.; Johnston, T.R.R. Agriculture in the City's Countryside; University of Toronto Press: Toronto, ON, Canada, 1992.

49. Capozza, D.R.; Helsley, R.W. The Fundamentals of Land Prices and Urban Growth. J. Urban Econ. 1989, 26, 295-306. [CrossRef]

50. Chicoine, D.L. Farmland Values at the Urban Fringe: An Analysis of Sale Prices. Land Econ. 1981, 57, $353-362$. [CrossRef]

51. Hushak, L.J. The Urban Demand for Urban-Rural Fringe Land. Land Econ. 1975, 51, 112-123. [CrossRef]

52. Hart, J.F. The Perimetropolitan Bow Wave. Geogr. Rev. 1991, 81, 37-51. [CrossRef]

53. Clawson, M. Urban Sprawl and Speculation in Suburban Land. Land Econ. 1962, 38, 99-111. [CrossRef]

54. Lin, G.; Ho, S. China's land resources and land-use change: Insights from the 1996 land survey. Land Use Policy 2003, 20, 87-107. [CrossRef]

55. Ji, C.Y.; Liu, Q.H.; Sun, D.F.; Wang, S.; Lin, P.; Li, X.W. Monitoring urban expansion with remote sensing in China. Int. J. Remote Sens. 2001, 22, 1441-1455. [CrossRef]

56. Fazal, S. The need for preserving farmland-A case study from a predominantly agrarian economy (India). Landsc. Urban Plan. 2001, 55, 1-13. [CrossRef]

57. Brown, L. Who Will Feed China? Wakeup Call for a Small Planet; W. Norton: New York, NY, USA, 1995.

58. Pepliński, B. External costs of open-cast lignite mining for the agri-food industry (as illustrated by the example of the Oczkowice mine). J. Agribus. Rural Dev. 2018, 2, 213-223. [CrossRef]

59. Zegar, J. Uwarunkowania i czynniki rozwoju rolnictwa zrównoważonego we współczesnym świecie. In $Z$ Badań nad Rolnictwem Społecznie ZrównoważOnym (15); Zegar, J., Ed.; IERiGŻ-PIB: Warszawa, Poland, 2012.

60. Tilman, D.; Balzer, C.; Hill, J.; Befort, B.L. Global food demand and the sustainable intensification of agriculture. Proc. Natl. Acad. Sci. USA 2011, 108, 20260-20264. [CrossRef]

61. FAO. How to Feed the World in 2050; FAO: Rome, Italy, 2009.

62. Furuseth, O.J.; Pierce, J.T. A comparative analysis of farmland preservation programmes in North America. Can. Geogr. 1982, 26, 191-206. [CrossRef]

63. Moran, W. Spatial patterns of agriculture on the urban periphery: The Auckland case. Tijdschrift Econ. Soc. Geogr. 1979, 70, 164-176. [CrossRef]

64. Bounce, M. Thirty years of farmland preservation in North America: Discourses and ideologies of a movement. J. Rural Stud. 1998, 14, 233-247. [CrossRef]

65. Kopsidis, M.; Wolf, N. Agricultural productivity across Prussia during the industrial revolution: A Thünen perspective. J. Econ. Hist. 2012, 72, 634-670. [CrossRef]

66. Frenkel, I. Ludność wiejska. In Polska Wieś 2018: Raport o Stanie Wsi; Wilkin, J., Nurzyńska, I., Eds.; Scholar: Warszawa, Poland, 2018; pp. 25-64.

67. Local Data Bank Central Statistical Office (CSO). Available online: bdl.stat.gov.pl/BDL (accessed on 25 September 2019).

68. Wilkin, J. Ewolucja wsi i rolnictwa w Polsce w okresie stulecia 1918-2018. In Polska Wieś 2018: Raport o Stanie Wsi; Wilkin, J., Nurzyńska, I., Eds.; Scholar: Warszawa, Poland, 2018; pp. 205-226.

69. Pepliński, B.; Poczta, W.; Rowiński, J. Struktura produkcji zwierzęcej i jej ewolucja. In Struktura Polskiego Rolnictwa na Tle Unii Europejskiej; Poczta, W., Rowiński, J., Eds.; CeDeWu: Warszawa, Poland, 2019; pp. 83-139.

70. Sadowski, A.; Czubak, W.; Poczta, W.; Rowiński, J. Struktury obszarowe i produkcyjne polskiego rolnictwa oraz innych państw unijnych. In Struktura Polskiego Rolnictwa na Tle Unii Europejskiej; Poczta, W., Rowiński, J., Eds.; CeDeWu: Warszawa, Poland, 2019; pp. 45-81.

71. Czubak, W.; Sadowski, A. Koncentracja i zmiany intensywności produkcji zwierzęcej w Polsce. Rocz. Nauk. SERiA 2013, 15, 100-104.

72. Olszańska, A. Rynek Żywca w Polsce (1955-2010)_Zmiany Strukturalne, Koncentracja Produkcji i Wahania Podaży; Uniwersytet Ekonomiczny we Wrocławiu: Wroclaw, Poland, 2012.

73. Sobczyński, T. Intensyfikacja i koncentracja produkcji a równowaga ekonomiczno-środowiskowa gospodarstw mlecznych i z chowem zwierzat ziarnożernych w UE. Rocz. Nauk. SERiA 2011, 13, 154-159.

74. Rozporządzenie Rady Ministrów z 5 czerwca 2018 r. w sprawie przyjęcia "Programu działań majacych na celu zmniejszenie zanieczyszczenia wód azotanami pochodzacymi ze źródeł rolniczych oraz zapobieganie dalszemu zanieczyszczeniu". Dz.U. 2018; Nr 134, poz. 1339. Available online: http://prawo.sejm.gov.pl/isap.nsf/ DocDetails.xsp?id=WDU20180001339 (accessed on 12 November 2019). 
75. Pepliński, B. Analiza regionalna zmian pogłowia trzody chlewnej w Polsce w latach 1960-2015. Rocz. Nauk. SERiA 2017, 19, 224-230. [CrossRef]

76. Ziętara, W.; Adamski, M. Skala produkcji, efektywność i konkurencyjność polskich gospodarstw wyspecjalizowanych w produkcji mleka. Zagad. Ekon. Roln. 2014, 1, 98-115.

77. Kopiński, J. Określenie stopnia polaryzacji głównych kierunków produkcji zwierzęcej w Polsce. Rocz. Nauk. SERiA 2014, 16, 142-147.

78. Sroka, W. Uwarunkowania rozwoju rozdrobnionego rolnictwa województwa młopolskiego. In Struktura Polskiego Rolnictwa na Tle Unii Europejskiej; Poczta, W., Rowiński, J., Eds.; CeDeWu: Warszawa, Poland, 2019; pp. 273-295.

79. Central Statistical Office of Poland (GUS). Rolnictwo na Terenach Miejskich w Województwie Mazowieckim; Urząd Statystyczny w Warszawie: Warszawa, Poland, 2013; pp. 29-30.

80. Stanisz, A. Przystępny Kurs Statystyki z Zastosowaniem STATISTICA PL na Przykładach z Medycyny, Tom II; StatSoft: Krakow, Poland, 2007.

81. Elektroniczny Podręcznik Statystyki PL. 2006. Available online: http://www.statsoft.pl/textbook/stathome. html (accessed on 27 February 2020).

82. Lockeretz, W. Secondary effects on midwestern agriculture of metropolitan development and decreases in farmland. Land Econ. 1989, 65, 205-216. [CrossRef]

83. Lopez, R.A.; Adelaja, A.O.; Andrews, M.S. The effects of suburbanization on agriculture. Am. J. Agric. Econ. 1988, 70, 346-358. [CrossRef]

84. Reynells, M.L.R. Urban sprawl as it affects the Southern California poultry industry. In Sustaining Agriculture Near Cities; Lockeretz, W.H., Ed.; Soil and Water Conservation Society: Ankeny, IA, USA, 1987; pp. 65-74.

85. Foltz, J.D. Entry, Exit, and Farm Size: Assessing an Experiment in Dairy Price Policy. Am. J. Agric. Econ. 2004, 86, 594-604. [CrossRef]

86. Sokolow, A.D. California's Edge Problem: Urban Impacts on Agriculture. In California Agriculture Dimensions and Issues; Siebert, J., Ed.; University of California: Davis, CA, USA, 2003; pp. 289-304.

87. Daniels, T. When City and Country Collide; Island Press: Washington, DC, USA, 1999.

88. Tarkowski, M. Ład przestrzenny jako czynnik rozwoju gospodarczego. Pomorski Przeglad Gospodarczy 2007, 2, 10-14.

89. Audirac, I. Unsettled Views About the Fringe: Rural-Urban or Urban-Rural Frontiers. In Contested Countryside: The Rural Urban Fringe in North America; Furuseth, O.J., Lapping, M.B., Eds.; Ashgate: Aldershot, UK, 1999; pp. 7-32.

90. Hart, J.F. "Rural" and "farm" no longer mean the same. In The Changing American Countryside; Castle, E.N., Ed.; University Press of Kansas: Lawrence, KS, USA, 1995; pp. 63-76.

91. Wolpert, J.; Danielson, M.N. The Rural Fringe in the New Metropolis. In National Rural Studies Committee; Castle, E.N., Baldwin, B., Eds.; Oregon State University: Corvallis, OR, USA, 1991; pp. 33-46.

92. Davis, J.S.; Nelson, A.C. The New Burbs: The Exurbs and their Implications for Planning Policy. J. Am. Plan. Assoc. 1994, 60, 45-60. [CrossRef]

93. Heimlich, R.E.; Anderson, W.D. Development at the Urban. Fringe and Beyond: Impacts on Agriculture and Rural Land, AER-803; United States Department of Agriculture: Washington, DC, USA, 2001.

94. Gradinaru, S.R.; Ioja, C.I.; Onose, D.A.; Gavrilidis, A.A.; Patru-Stupariu, I.; Kienast, F.; Hersperger, A.M. Land abandonment as a precursor of built-up development at the sprawling periphery of former socialist cities. Ecol. Indic. 2015, 57, 305-313. [CrossRef]

95. Xie, H.; Wang, P.; Yao, G. Exploring the dynamic mechanisms of farmland abandonment based on a spatially explicit economic model for environmental sustainability: A case study in Jiangxi Province, China. Sustainability 2014, 6, 1260-1282. [CrossRef]

96. Mazzocchi, C.; Sali, G.; Corsi, S. Land use conversion in metropolitan areas and the permanence of agriculture: Sensitivity Index of Agricultural Land (SIAL), a tool for territorial analysis. Land Use Policy 2013, 35, 155-162. [CrossRef]

97. Gellrich, M.; Zimmermann, N.E. Investigating the regional-scale pattern of agricultural land abandonment in the Swiss mountains: A spatial statistical modelling approach. Landsc. Urban Plan. 2007, 79, 65-76. [CrossRef]

98. Hagedorn, K. Property rights reform on agricultural land in Central and Eastern Europe. Q. J. Int. Agric. 2004, 43, 409-438. 
99. Diogo, V.; Koomen, E.; Kuhlman, T. An economic theory-based explanatory model of agricultural land-use patterns: The Netherlands as a case study. Agric. Syst. 2015, 139, 1-16. [CrossRef]

100. Ewert, F.; Rounsevell, M.D.A.; Reginster, I.; Metzger, M.J.; Leemans, R. Future scenarios of European agricultural land use: I. Estimating changes in crop productivity. Agric. Ecosyst. Environ. 2005, 107, 101-116. [CrossRef]

101. Müller, D.; Zeller, M. Land use dynamics in the central highlands of Vietnam: A spatial model combining village survey data with satellite imagery interpretation. Agric. Econ. 2002, 27, 333-354. [CrossRef]

102. Sroka, W.; Pölling, B. The Potential and Significance of urban Agriculture on the basis of the Ruhr Metropolis and the Upper Silesian Metropolis. Probl. World Agric. 2015, 15, 180-193.

103. Burmeister, L.L. Lagoons, Litter and the Law: CAFO Regulation as Social Risk Politics. South. Rural Sociol. 2002, 18, 56-87.

104. Harris, C.K.; Bailey, C. Public Support for a Clean, Green, U.S. Agriculture Machine. In The Social Risks of Agriculture; Wimberley, R.C., Harris, C.K., Molnar, J.J., Tomazic, T.J., Eds.; Praeger Publishers: Westport, CT, USA, 2002; pp. 31-42.

105. Roper, A.S.W. Examining Consumer Expectations of Agriculture; Altria Corporate Services, Inc.: Richmond, VA, USA, 2002.

106. Wachenheim, C.J.; Rathge, R. Residence and Farm Experience Influence Perception of Agriculture. Rural Am. 2002, 16, 18-29.

107. Gollehon, N.; Caswell, M. Confined Animal Production Poses Manure Management Problem. Agric. Outlook 2000, 9, 12-18.

108. Mallin, M.A. Impacts of Industrial Animal Production on Rivers and Estuaries. Am. Scientist. 2000, 88, 26-37. [CrossRef]

109. Constance, D.H.; Bonanno, A. CAFO Controversy in the Texas Panhandle Region: The Environmental Crisis of Hog Productions. Culture Agric. 1999, 21, 14-26. [CrossRef]

110. Jackson, L.L. Large-Scale Swine Production and Water Quality. In Pigs, Profits, and Rural Communities; Thu, K.M., Durrenberger, E.P., Eds.; State University of New York Press: Albany, NY, USA, 1998; pp. 103-119.

111. Durrenberger, E.P.; Thu, K.M. The Expansion of Large Scale Hog Farming in Iowa: The Applicability of Goldschmidt's Findings Fifty Years Later. Hum. Organ. 1996, 55, 409-415. [CrossRef]

112. Sharp, J.S.; Smith, M.B. Social Capital and Farming at the Rural-Urban Interface. Agric. Syst. 2003, 76, 913-927. [CrossRef]

113. Kelsey, T.W.; Vaserstein, G. Farming and Nonfarming Neighbors: Conflict, Coexistence, and Communication. J. Soil Water Conserv. 2000, 55, 462-466.

114. Owen, L.; Howard, W.; Waldron, M. Conflicts Over Farming Practices in Canada: The Role of Interactive Conflict Resolution Approaches. J. Rural Stud. 2000, 16, 475-483. [CrossRef]

115. Eakin, H.; York, A.; Aggarwal, R.; Waters, S.; Welch, J.; Rubiños, C.; Smith-Heisters, S.; Bausch, C.; Anderies, J.M. Cognitive and institutional influences on farmers' adaptive capacity: Insights into barriers and opportunities for transformative change in central Arizona. Reg. Environ. Change 2016, 16, 801-814. [CrossRef]

116. Marshall, N.A.; Park, S.E.; Adger, W.N.; Brown, K.; Howden, S.M. Transformational capacity and the influence of place and identity. Environ. Res. Lett. 2012, 7, 034022. [CrossRef]

117. Fresque-Baxter, J.A.; Armitage, D. Place identity and climate change adaptation: A synthesis and framework for understanding. Wiley Interdiscip. Rev. Clim. Change 2012, 3, 251-266. [CrossRef]

118. Adger, W.N.; Barnett, J.; Chapin, F.S., III; Ellemor, H. This must be the place: Underrepresentation of identity and meaning in climate change decision-making. Glob. Environ. Politics 2011, 11, 1-25. [CrossRef]

119. Lisansky, J.; Clark, G. Farmer-nonfarmer conflicts in the urban fringe: Will right-to-farm help? In Sustaining Agriculture near Cities; Lockeretz, W., Ed.; Soil and Water Conservation Society: Ankeny, IA, USA, 1987; pp. 219-230.

120. Ustawa o minimalnej odległości dla planowanego przedsięwzięcia sektora rolnictwa, którego funkcjonowanie może wiązać się z ryzykiem powstawania uciążliwości zapachowej; Draft Act of 28 March 2019. Available online: https://legislacja.rcl.gov.pl/projekt/12321413/katalog/12579307\#12579307 (accessed on 7 January 2020). 